\title{
Students as co-learners - reviewing a decade of the
}

\section{Geography Research Assistantship}

\author{
Fiona S. Tweed
}

Geography, Staffordshire University, College Road, Stoke-on-Trent, Staffordshire, ST4 2DE, UK

Correspondence to:

Prof. Fiona Tweed

Email: f.s.tweed@staffs.ac.uk

Tel.: +44 (0) 1782294113 
Increasing attention is focusing on the creation of academic spaces in which students can engage with research and inquiry. This paper reports on the Geography Research Assistantship (GRA) module developed and implemented in Geography at Staffordshire University and reviews its contribution to student learning over the last decade. The GRA offers final year undergraduate students the opportunity to work as research assistants to members of staff and external collaborators. The experiences of students, staff and external collaborators involved in a range of research assistantships over the last ten years are reviewed and the main benefits, challenges and impacts of the initiative are analysed. The GRA engenders co-learning environments, characterised by engagement in the iterative practices of research and inquiry and the development of confidence, internal authority and self-authorship. Some students experience unease in adjusting to the liminal learning spaces inherent in the GRA and there are tensions in the exclusivity of the initiative. Evidence underscores the value of cultivating co-learning relationships and environments for mutual benefit and we encourage others to identify opportunities for adopting similar initiatives.

Keywords: research-engaged learning, undergraduate, co-creation, graduate attributes, learning landscape, employability 
The links between learning, teaching and research in higher education are frequently deliberated. The nature of the research-teaching 'nexus' has tended to dominate academic discussion; however, it has become generally accepted that actively engaging undergraduate students in their learning experiences has positive benefits for students, staff and external actors (e.g. Jenkins, 2000; Healey, 2005; Healey and Jenkins, 2009; Neary et al., 2014; Fung, 2017) and, although the connections between research and teaching are still debated, work has moved on to consider how student research and inquiry are implicated in the development of other attributes and outcomes. Recent studies have explored the links between inquiry-based learning in the workplace and employability (e.g. Eden, 2014); different ways of engaging students with academic research (e.g. Dexter and Seden, 2014; Walkington, 2015; Speake, 2015); co-learning and partnership in higher education (e.g. Hill et al., 2013; Fuller et al., 2014; Healey et al., 2014); the development of student self-authorship (e.g. Baxter Magolda, 2007; Hodge et al., 2009; Moore et al., 2011) and the nature of the pedagogic spaces in which learning partnerships take place (e.g. Walkington et al., 2011; Hill et al., 2016).

This paper contributes to the body of work on the co-creation of knowledge, working in partnership and the development of self-authorship, by reviewing the experiences of undergraduate students, staff and external collaborators who have participated in Staffordshire University's Geography Research Assistantship (GRA) since its inception in 2008. This study builds on initial work described in Tweed and Boast (2011) and is in part stimulated by reviewers' comments on that work, which urged us to provide an update on the experiences of running the module when it had become established. The paper begins with a short summary of the context in which the initiative is embedded, focusing on recent developments in research-engaged learning and teaching and the wider backdrop of changes in higher education; these frame the evaluation of the GRA and the subsequent discussion. Given the established and wide-ranging nature of the literature on researchengaged learning and teaching, the intention here is to direct the reader towards key themes which will be referred to later. In seeking to highlight relevant work, studies that are embedded in a Geography setting have been given prominence. 


\section{2) Research-engaged learning and teaching in context}

There have been significant developments in research-engaged learning over the last three decades. The nature of the 'research-teaching nexus' and the effectiveness of inquiry-based learning and teaching was often debated in the 1990s and 2000s; McLean and Barker (2004) and more recently Tight (2016) provide useful outlines of the research-teaching debate, for those unfamiliar with it. In essence, some researchers claim that evidence for links between research and teaching is at best tenuous (e.g. Hattie and Marsh, 1996; Marsh and Hattie, 2002; Kinchin and Hay, 2007) and others maintain that the two activities are inextricably linked (e.g. Brew, 2003; Healey et al., (2003); Jenkins, 2004; Healey, 2005). There is undoubtedly evidence that lecturers who are involved in research are viewed by their students as 'credible' with 'enhanced knowledge currency' (Lindsay et al., 2002; Kinchin and Hay; 2007; Healey et al. 2010), but some challenge the assumption that good researchers make good teachers and others note ambivalences in reflections on the researchteaching nexus and in the experience of research-engaged learning (e.g. Simons and Elen, 2007; Zamorski, 2010).

Work by Brew (1999; 2003; 2006), Jenkins et al., (2003); Jenkins (2004), Healey (2005), Jenkins and Healey (2005), Le Heron et al., (2006), Robertson (2007) and Healey and Jenkins (2009) amongst others, shifted the ground and by the end of the first decade of the twenty-first century, many had embraced what they saw as the inherent nature of the links. The essence of the debate periodically re-surfaces, but it has been gradually eclipsed by consensus that participation in research is a vital part of undergraduate learning and by research that seeks to cement the relationship between research and teaching. For example, Cuthbert (2009) integrates teaching, learning, research and scholarship by referring to them holistically as 'academic practice' as a means of encouraging higher education institutions to devise integrative approaches. This corresponds with work by Jenkins (2004), Healey (2005), Brew (2006) and Schapper and Mayson (2010) all of whom stress the need to reconsider the idea of scholarship, to establish a culture of inquiry, to develop communities of practice in which participants are prepared to cope with uncertainty and interdependence and to reshape teaching and research from product-based to process-based endeavours. Focus has gradually shifted from teaching to learning, putting the student at the centre of education (Simons and Elen, 
2007) and emphasizing processes of inquiry, rather than outcomes, as being central to learning (Moore-Cherry et al., 2016).

The evolving nature of higher education has also seen increased emphasis on employability and graduate attributes, which in turn has led to re-evaluation and re-framing of curricula, especially regarding skills. Graduate attributes were adopted in Australian universities and have become established over the last twenty years. However, despite the focus on employability in the UK over the last decade, there is little true consensus in the literature regarding definitions of graduate employability (Eden, 2014). Whilst some skills defined as desirable by employers are obvious and familiar, others are more difficult to identify and measure. Researchers have recognized that employers tend to be satisfied with technical skills in their graduate workforce and less satisfied with social skills (e.g. CBI, 2012; Eden, 2014). Qualities such as reflection and evaluation, emotional intelligence, negotiation, personal experience, problem-solving, initiative and confidence feature large in what many employers are now seeking (Johansson and Felton, 2014) and also in viewing employability as 'a process of 'becoming' related to graduate identity' (Pegg et al., 2012 p.20), rather than being defined by a functional list of technical and operational skills. As observed by Simons and Elen (2007), there is an overlap between research core skills and employability core skills, a parallel drawn several years before: "It is very striking that the list of employability competencies overlaps quite largely with the competencies involved in the exercise of modern research activity" (Commission of the European Communities, 2002, p.40).

Despite advances that seem to unite research and teaching, researchers have observed that the relationship between the two has a political dimension and that true synergy is frequently undermined by the separate ways in which they are each managed, assessed and funded, especially in the UK (e.g. McLean and Barker, 2004; Tight, 2018). Policy developments have put pressure on the traditional idea that academic staff should be both teachers and researchers (Palfreyman and Tapper, 2009; Geschwind and Broström, 2015) and debates about research and teaching cannot be separated from the evolving nature of higher education and society's expectations of it. The learning landscape is being moderated by the multiplicity of drivers for change and the developing neoliberal context in which higher education is set. Increasing marketisation and metrication, social, technological and economic transformation and the employability agenda are all interwoven in the changes that are 
ongoing (e.g. Eden et al., 2014; Hill et al., 2016). The traditional relationships between students and 'teachers' are shifting. In addition, the range of stakeholder interests in universities has become much more prominent, with community engagement, volunteering, employability and workplace opportunities increasingly available alongside more traditional educational activities (e.g. Arrowsmith et al., 2011; Eden, 2014). The conventional nature of research in higher education has evolved in response to societal and technological change 4.0 (e.g. Aoun, 2017; Morrar et al., 2017) and universities are increasingly seen as centres of innovation and creativity. Learning to construct knowledge in an independent way involves the acquisition of a set of useful skills from the perspective of a knowledge society and its expectations of higher education (Brew, 2003; Simons and Elen, 2007; Hill and Walkington, 2016; Hill et al., 2016). Universities aim to enable their students to acquire high level subject-based research and a set of personal competencies to prepare them for positions in society (Arrowsmith et al., 2011; Decker and Wolff, 2016), but the current pace of societal change means that many jobs of the future are difficult to pre-imagine. What core social skills and attributes will students need and by what mechanisms can their acquisition be achieved, are questions that frequently re-surface.

Many learners rely on perspectives and knowledges that have been uncritically accepted from others. However, the development of internal authority and empowerment to assume greater agency over, and responsibility for, the discovery process and the learning environment characterise the shift to self-authorship, which has become a prominent quality discussed in the context of inquiry-based learning and teaching and employability skills (e.g. Baxter Magolda, 2004; Mitchell, 2006; Hodge et al., 2009; Moore et al., 2011).There is now a significant body of work that specifically highlights the benefits and challenges of co-production, working in partnership, co-creation of knowledge and the development of self-authorship within research-engaged learning settings (Moore et al., 2011; Healey et al., 2014; Moore-Cherry et al., 2016; Hill et al., 2018). Some have described how schemes have been embraced at institution-wide level; for example, Hodge et al., (2009) report on 'The Engaged Learning University' initiative at the University of Miami, USA and Neary et al., (2014) explain 'student as producer', a curriculum development project that promotes research-engaged teaching as the organising principle for teaching and learning across all subjects and all levels of taught provision at the University of Lincoln, UK. 'The Connected Curriculum' (Fung, 
2017) has been employed as a transformative educational strategy across University College London, UK; this bold approach is designed to unite university research and student education with staff and students engaged in genuine critical dialogue. The de-stabilisation of traditional power hierarchies within higher education is permitting different collaborative spaces to emerge, which in turn are enabling the construction of new student identities (Hill et al., 2016; Hill et al., 2018) and holistic approaches to learning.

In summary, there has been a range of recent studies that highlight settings and circumstances in which research, teaching and learning connect. It is within the evolving educational context described above that this reflection on a decade of running the GRA is set.

\section{Geography at Staffordshire University and the Geography and Environment Research Assistantship}

Geography at Staffordshire University is nationally recognized for its learning and teaching excellence and consistently scores well in external assessments of teaching quality and student satisfaction. Inquiry-based and research-engaged learning and teaching form a core element of undergraduate provision in Geography at Staffordshire University; these approaches to learning have been embedded in our curricula for over twenty-five years (e.g. Harris and Tweed, 2010; Tweed and Boast, 2011) and are repeatedly commended. Students gain knowledge and understanding of staff research through content-based, research-informed modules and they conduct their own research, both individually and in groups, as part of project work linked to some thematic modules, skills workshops and residential fieldwork at all three levels of their undergraduate degree. Students also gain experience of volunteering and the wider context of Geography research and inquiry through a module 'Geographers in the Real World' in their second year, at which point they also undertake comprehensive project scoping, design and planning for their undergraduate dissertation. The bulk of the work for their dissertation is undertaken during the autumn of their third year. Whilst there is currently no formal institutional framework for embedding research and inquiry, Geography students are consistently involved in research-led and research-engaged learning, which forms a strong foundation for the undergraduate dissertation - and for the GRA. Students are therefore familiar with the ways in which geographical knowledge is both generated and disseminated. 
The GRA is a final year undergraduate 15-credit option module that offers students the opportunity to work as a co-learner on a research project, supervised by a member of staff. On some projects, the research is triggered by the needs of external collaborators who also work in partnership with staff and the student. The GRA is a research-engaged form of learning and teaching (see Jenkins, 2000; Griffiths 2004; Healey, 2005; Dexter and Seden, 2012; Speake, 2015). In recognition of the largely untapped research capital in the student body, the GRA was devised to give students the opportunity to become involved in research alongside academic staff and external collaborators. The projects with which students assist are founded on an issue that can be examined through fieldwork, library or archival investigation, or by the analysis and/or presentation of data. Research outputs are highly varied and linked to the nature of the project. We piloted the GRA as a learning and teaching experiment in 2007-08 with two assistantships and subsequently funded three assistantships in 200809 as part of a research-informed teaching project. Based on the successful trial stages of the module, we subsequently made it available as a final year Geography option module in 2009. The GRA has been consistently praised by external examiners who have commended it as an exemplar of innovative pedagogy and the experience of designing and running the GRA has been disseminated nationally at the RGS-IBG annual conference in 2015 and as an invited talk at the RGS-IBG Geography and Employability workshop in 2016.

An introductory account of the development of the module and an initial review of the impacts on student learning are presented in Tweed and Boast (2011), which was also selected for re-publication as part of a special issue (see Haigh et al., 2016). Here greater analysis can be provided along with further insights due to a more substantial data set, ten years' experience of running the module and the backdrop of the changing environment of research-engaged learning in higher education. In particular, this paper focuses on: i) the nature of the research in which students have been engaged; ii) the research-engaged learning experience from a student and staff perspective; iii) the experience of the research assistantship from the viewpoint of external collaborators and iv) the wider context of the co-creation of knowledge and ownership of learning. A set of specific questions frame the paper: How do students perform on the GRA? What attributes and skills do they identify they have gained? What do students see as the benefits and challenges of this type of researchengaged learning? What are staff and external collaborators' experiences of the GRA? What is the 
role of the GRA in the context of the evolving nature of curricula and skills development in higher education?

\section{Methods of inquiry}

The GRA has been subject to ongoing evaluation using a range of indicators and approaches. Formal feedback has been collected from GRA students at the end of their assistantship experience using a bespoke module feedback questionnaire which has remained consistent since 2008-09, thereby enabling comparison from year to year (Tweed and Boast, 2011). The questionnaire comprises eight closed questions consisting of statements to which responses are acquired on a fivepoint scale usually from 'strongly agree' to 'strongly disagree' and ten open questions that permit more free-ranging responses. Comments from the questionnaire were collated and coded to identify key themes. Data from the questionnaire has been augmented by elements of the final report that students produce, which has a reflective element, from which some comments have been distilled. Informal feedback from students is common because of the nature of the activities and the forms of learning in which they are engaged and has been noted. A record of module marks as well as overall degree marks also enables some simple observations regarding traditional measures of student 'performance' to be made. Comments from members of staff and external collaborators have been collated.

Figure 1 is a record of the research projects onto which we have recruited GRA students, signaling those projects that have involved the students actively engaging with external collaborators. Seven vignettes have been developed (Figures 2 and 3) that spotlight the range of research activities in which students have been engaged and draw upon the student and staff experiences of the GRA. These vignettes are referred to in the discussion below, alongside other evidence drawn from the sources outlined above.

\section{The nature of the work in which students have been engaged}

To-date, we have had 40 GRA students who have been engaged in a range of projects working with members of staff in Geography, and more widely across the University as well as with external collaborators (Figure 1). We have usually recruited 3-7 students per year to research assistantship 
projects, depending on the availability of projects and the size of the final year undergraduate group; as an indicator, GRAs usually comprise approximately $10 \%$ of the year group. Student cohorts differ; in some years we have had a lot of competition for the projects offered and in other years, much less so. For example, in 2016-17, we offered two GRA positions on two different projects and neither of these was taken up, so we rested the module that year. The gender split in GRAs that we have recruited has been roughly equal (22 male and 18 female). Students are assessed by a presentation and a reflective report (Tweed and Boast, 2011), both in the late stages of the module. These assessments draw upon the research that has been done, but also provide an opportunity for selfreflection. In addition, neither of the assessments rely on specific project-defined research outcomes, thereby constituting a consistent and equitable way of judging student performance as defined by the need to assess the module. However, this does generate some tensions, as commented upon later.

The 40 GRAs to-date have worked on a range of projects, some pure research, others more applied and some consultancy and work-based opportunities (see Figure 1). All the projects have research at their core, but the range of projects varies yearly according to the needs of staff and external collaborators. Vignettes (Figures 2 and 3 ) exemplify the range of activities undertaken by GRA students working with staff and sometimes with external collaborators. Some GRA students have co-worked on literature reviews with staff (Vignettes 1 and 6); some have analysed data (Vignettes 5 and 6); others have been engaged in working with local communities (Vignette 3) or with companies (Vignettes 2 and 4) to achieve specific research-based outcomes and almost all GRA students have contributed to written reports or similar outputs. A set of GRA students have been engaged in developing learning materials for use in schools (Vignette 7), working with outreach coordinators, University staff and school teachers; these projects have involved GRA students researching learning styles and developing useful resources to address subject matter with which school students experience difficulty.

\section{Student experience and perspectives}

Figure 4 illustrates the performance of students in assessment for the GRA. Most students are awarded upper-second class and first-class marks and some students achieve very high marks. This 
is to be expected; GRA students are essentially self-selecting as they are required to put themselves forward for the opportunities. It is difficult to unpick the relationships here and it would be invidious to attempt to do so; do students do well because they have responded favourably to the learning opportunity or do they choose - and are they ultimately selected for - the learning opportunity because they have qualities or aspirations that mean that they are more likely to apply to do so than their peers (see Mason et al., 2009; Eden, 2014)? Common sense dictates that it is likely to be a mixture of both.

The closed questions section of the student feedback survey permits some evaluation of student experience of the GRA (Figure 5). All students agree or strongly agree that the module is taught in a different way from other final year undergraduate modules, which is to be expected. Most students agree or strongly agree that the work in which they have been involved has encouraged them to achieve a deeper level of knowledge generation compared to other final year modules, although one student strongly disagreed with this statement. When asked whether the GRA had enabled them to gain greater specialist knowledge, most students agreed or strongly agreed that it had, but one student strongly disagreed. Most students identify the learning on the GRA to be harder than other final year modules, with a minority of students declaring it to be the same, easier or much easier. Most students would have welcomed the opportunity to do more modules like the GRA elsewhere on their course, with two students responding neutrally to the statement and one student strongly disagreeing. The students' self-assessment of the amount of time that they spent on the GRA varied; most students opted for 15 credits (which translates to 150 hours), but a significant proportion of participants estimated that they were involved in the GRA for 300 hours or over. All students strongly agreed or agreed that they were broadly satisfied with the module, bar one who was neutral in response to the statement. It is important to note that the disagreeing and neutral responses on the student feedback questionnaire were associated with a single GRA student; these are the only negative or neutral reactions that we have received in ten years of running the GRA.

GRA students were asked to identify skills that they thought that they had acquired on the module (Figure 5). This is an open question on the student feedback survey. Students repeatedly cited collaboration, communication, time management, organization and independence in this context, rather than subject-specific competencies. Likewise, when asked about the attributes and 
aptitudes that are needed in order to do the GRA (Figure 6), students overwhelmingly identified generic skills such as enthusiasm and motivation, commitment, independence, determination, organization and time management. GRA students perceive the importance of more general skills and attributes over technical or subject-specific competencies which is encouraging, given the strong steer from employers on the need for these qualities (CBI, 2012; Pegg et al., 2012; Eden, 2014; Johansson and Felton, 2014). However, it is important to stress that student responses are conditioned by their view of the terms 'skills' or 'attributes'.

Although confidence as a skill or attribute does not feature prominently in the above (Figure 5), student comments in Vignettes 1-7 endorse the fact that, when reflecting on the experience of doing the GRA, the development of confidence is key. Confidence is also repeatedly mentioned in the free-text sections of the student feedback questionnaire; for example: "It's given me a confidence boost knowing I am able to apply my skills in real life research" and "I enjoyed working with a lecturer in a different dynamic than before, this gave me confidence in my work and a motivation to do well". Students frequently speak of the enjoyment gained from their involvement in the research (e.g. Vignettes 2 and 5), their sense of pride and the fact that that they found the GRA "rewarding" and "satisfying". Comments in Vignettes 5 and 6 refer to disappointment at the experience ending and the desire to continue with the research, despite the formal end of the work; it is clear that for some, the interest that they have - or have developed - in the work has instilled or maintained a high degree of motivation. When completing the feedback questionnaire several students mentioned the sense of "accomplishment" and "achievement" that they gained from the work that they had produced or been involved in. Other students identified the different way of working as a "chance to take control of your own learning" and "being in charge of my own learning" and appreciated the advantages of the close working relationships that evolved: "It was rewarding to have one-to-one feedback and encouragement helping you to identify personal strengths and weaknesses". Evidence from student feedback clearly suggests that students recognize that they are occupying new (co)-learning spaces (see Speake, 2015; Hill et al., 2016); this is apparent from comments in the vignettes and also from free-text responses in the student feedback questionnaire, for example: "A different relationship with the staff member evolves - you become a co-worker" and "The relationship with X evolved; I was 
learning alongside him". GRA students demonstrate awareness of having agency and ownership as co-producers of original work and new knowledge.

Comments as part of student feedback on the GRA experience recognise the reciprocal and iterative nature of the work and the need for questioning, review and collaboration to develop new knowledge. Critically, many students observed that these processes became part of their learning routine outside of the requirements of the GRA (e.g. Vignette 6). Students became more reflexive about their learning and the development of their own research skills and the place of research in that (see particularly Vignettes 1 and 6). Many students gained confidence in their critical evaluation of the work of others, as found by Speake (2015) and Hill et al., (2016); this is particularly evident in the GRA comments in Vignettes 2, 4 and 6. Co-designing the work develops intellectual maturity in a supportive environment and challenges some of the established boundaries in higher education. There is also recognition of the work having meaning, impact and relevance beyond the needs of the curriculum, upon which students comment in their feedback (e.g. Vignette 4).

Some students have expressed anxieties at the start of the process of undertaking a GRA; sometimes this has been not knowing what to expect and what might be before them, given the iterative nature of research. This could be to do with a shift as they take on the responsibility of colearning and occupy unfamiliar territory and it is expected that some degree of unease would be encountered in adjusting to this liminal space; for example, see Felton (2011) on the 'messy' aspects of productive disruption and related observations made by Hill et al., (2016). Some research projects have been more clearly mapped out than others and we have observed that some students find it challenging to be met by staff uncertainty regarding how the project might develop; for example, in free-text responses on the feedback questionnaire, students noted: "I would have liked clearer expected outcomes at the start of the project" and "Sometimes it was left to me to put expectations on myself; although this is not necessarily a negative point". Observations from some students signal that they have also been surprised and challenged by the expectations of academic writing (e.g. Vignette 6), but that this subsequently translated into them becoming reflexive about their own research skills development and more able to critically analyse the work of others, as observed by Speake (2015) 


\section{Staff and external collaborator experience and perspectives}

The GRA engenders a very real sense of 'practising geography' and of the participants (students, staff and external collaborators) taking ownership of the research work, which they can all see endures beyond the functional elements of curriculum, such as the need for assessment. Members of staff have been empowered to form different working relationships with GRA students. Over the course of running the GRA, students and staff have worked in partnership with collaborators in a range of external organizations; for example, local councils, environmental charities and not-forprofit companies, SMEs, The Environment Agency, a local residents' association and an engineering firm. This has inspired people in these organizations to recognize the processes involved in student learning and to work differently to support it. The external collaborator in Vignette 4 clearly identifies the development of talent and ability, but pinpoints increasing confidence as the key attribute enhanced by GRA students working with their organization. External collaborators also recognize the positive nature of the reciprocal relationship between them and the GRA (Vignettes 3 and 4) and in the case of Vignette 3, the contribution that the wider community can make to student learning. The value of the research and the benefits to the external organization are exemplified by the staff and collaborator comments in Vignette 4. Even when the research project has not been conducted in formal collaboration with an external collaborator, on some occasions the results of the research have been of direct interest to particular organisations, who have been invited to engage with the findings (for example, Vignette 5).

Staff, students and external collaborators have observed the adjustments made by all actors in growing into their roles in these new permissive pedagogic spaces (Hill et al., 2016). Anecdotal evidence from staff suggests that that there is degree of difference in approach taken by students which depends what kind of GRA they are involved in. Those working externally have so far seemed keen to be seen as 'consultants in the workplace' frequently adopting smarter dress, for example. Those who were working internally, but visibly taking on a new role for the University, were inclined to do the same. Those whose physical presence involved less interaction with external groups of people (e.g. students doing fieldwork, archival or laboratory work rather than consultancy) have tended to behave more like research students. 
Some graduates who were GRAs have since gained employment and have been instrumental in encouraging their new workplaces to establish 'second generation' GRA relationships with us as external collaborators, further demonstrating the diffusion of the model and its ability to cultivate environments in which learning takes place. Students have also secured employment as a direct result of their GRA experience, and the skills that they have acquired as part of that experience, particularly where this has involved external collaboration.

\section{The evolving nature of the GRA}

The essence of the GRA has remained constant since its inception; it is an option module with participation controlled by a competitive application process, mirroring the selection procedure for most employment or volunteering opportunities outside higher education. We have returned several times to consider the assessment of the work that students do, and we have retained the presentation and reflective report (see Tweed and Boast, 2011). There is a need for parity in assessment and, given the range of research activities in which a GRA student could be engaged, it would be difficult to design bespoke criteria for those different aspects of work and their potential outputs. Some students find this difficult to navigate as it can seem as if there is another 'layer' of work on top of the research processes and/or products. We have altered the balance of marks between report and presentation from 70:30 to 50:50 based on student feedback and review as people felt that the effort involved in developing the presentation was at least equal to writing the reflective report. This has been positively received. On the basis of some student feedback, we are also currently debating the practicalities of having an end of module 'conference' at which the GRA students present their findings; some GRA students have expressed a desire to learn more about the activities in which others working on different GRA projects have been involved.

Feedback from students suggests that many would welcome more opportunities of this nature throughout their degree and that they would have liked a larger range of prospective projects when applying for GRA positions. There is some tension here in that, whilst it would be desirable to try to adapt the GRA to make it more inclusive (see Moore-Cherry et al., 2016), in practice there are issues of co-working 'critical mass' in terms of suitable projects, available time and resources and the extent to which each opportunity can be made fully inclusive. The selection process for the GRA 
421 reflects the post-educational environment; not everyone who applies for a job is suited to the post and not everyone wants that particular opportunity anyway. On balance, over the last ten years, despite the comments of those wanting a larger range of projects from which to choose, 'supply' (the range of opportunities) has been roughly balanced by 'demand' (the number of applications for those projects). Rarely have there been more than two applications for one opportunity, although we have observed that some students apply for more than one GRA project.

The range of outputs generated by GRAs has been highly varied, as has the research in which they have been engaged; this is appropriate preparation for the variety of roles that graduates will move into. Over the last decade, the GRA has become less unusual as a learning endeavour as students in Geography and more widely across the University have placement, work-based learning and volunteering opportunities embedded in their awards and in specific modules - some inclusive, others exclusive. This has been a common development across the higher education sector (Arrowsmith et al., 2011; Eden, 2014). As we move further into the $21^{\text {st }}$ Century, there is increasing emphasis on the need for innovation and creativity in graduate employment, which the development of a range of skills and aptitudes associated with research-engaged learning, such as the experiences acquired through the GRA, can help to enhance. The GRA as outlined here is a flexible framework for learning, which can be employed alongside other more traditionally taught modules or adapted to function as an element of more ambitious and dedicated cross-institution research-engaged learning initiatives, such as those advocated by Neary (2014) and Fung (2017).

The co-learning experience that characterises the GRA is distinct and different from many other forms of research-based or research-engaged education. For example, advising students on the design and implementation of research as part of a dissertation project does not require the supervising staff member to be actively engaging in research themselves. Further work could explore the similarities and differences between research-engaged co-learning experiences and other forms of research-based learning, both from a student and a staff perspective. It would also be valuable to determine the extent to which successful research-engaged co-learning is dependent on the existence, nature and timing of other research-based modules and to identify the key relationships involved. 


\section{Conclusions}

The landscape of learning is rapidly evolving as higher education providers grapple with the changing and sometimes elusive nature of the skills, attributes and aptitudes that will be needed for the occupations and activities in which students will be involved after they graduate (Johansson and Felten, 2014; Aoun, 2017). Increasing attention is being focused on the creation of academic spaces in which students can engage with research cultures (Walkington et al., 2011; Hill et al., 2013; Speake, 2015) and thereby acquire a range of skills and attributes that are sought by employers. Additionally, there is a growing reconceptualization of learning and teaching as a collaborative process (Hill et al., 2016). The GRA is an example of innovative practice in developing co-learning environments in a higher education context. It enables students to have agency in the co-production of knowledge, characterized by engagement in the iterative practices of research. Evidence suggests that the GRA makes research accessible and 'real' and that it capitalizes on mutual enthusiasm. It enables students to acquire a range of generic attributes, transferable skills valued by employers, such as independence, collaboration, time management and organization and, critically, it builds and/or develops confidence (Eden, 2014). Like Speake (2015), we have observed how GRA students became more reflexive about their own research skills development and more able to critically analyse the work of others as a consequence of their GRA experience. The GRA encourages staff and external collaborators to work differently, (co-) occupying new pedagogic spaces that emphasise processes of inquiry and co-learning and in which the practices of traditional higher education are transformed.

The GRA as presented here is not an inclusive learning partnership as advocated by MooreCherry et al., (2016), and is open to criticism on those grounds, but it could provide an introduction to different ways of working, for both students and staff, in those learning contexts in which curriculum designers are seeking to diversify academic practice and to enable a wider range of student experiences. We encourage others to reflect on opportunities for co-learning in their academic programmes and we advocate the GRA as a relatively straightforward framework for learning that can be introduced alongside other modules. The GRA could also be employed as part of a more radical transformation of curricula or institution-wide initiative in which students are more widely working in partnership and/or engaging in co-production (e.g. Neary et al., 2014; Fung, 2017), 
478 providing there are sufficient opportunities for genuine research-engaged co-learning and the

479 necessary resources to support its inclusive adoption.

480

481

\section{Acknowledgements}

Thank you to GRA students, staff and external collaborators who have worked on a range of projects and given their feedback so freely over the last decade, during which time this learning initiative has become embedded. I am grateful to the participants of RGS-IBG Employability Day 2016 for their comments on the GRA. The piloting of the GRA module was supported by funding from HEFCE, which was deployed by the Academic Development Institute at Staffordshire University as part of an initiative to enhance links between learning, teaching and research. Thank you to Janet Wright, Ruth Swetnam and Gordon Walker for helpful comments on an earlier draft of this paper. I am grateful to two anonymous reviewers and the editor, all of whom provided useful suggestions that helped to improve the manuscript. 
Aoun, J.E. (2017). Robot-Proof: Higher Education in the Age of Artificial Intelligence. The MIT Press, 496 Cambridge, MA, USA.

497

Arrowsmith, C., Bagoly-Simó, P., Finchum, A., Oda, K. \& Pawson, E. (2011). Student Employability and its Implications for Geography Curricula and Learning Practices. Journal of Geography in Higher Education, 35, 365-377.

501

Baxter Magolda, M.B. (2004). Self-authorship as the common goal of $21^{\text {st }}$ century education. In: Baxter Magolda B. and King, P.M. (Eds.) Learning partnerships: theories and models of practice to educate for self-authorship. Stylus Publishing, LLC, USA.

Baxter Magolda, M.B. (2007). Self-Authorship: The Foundation for Twenty-First-Century Education. New Directions in Learning and Teaching, 109, 69-83.

Brew, A. (1999). Research and Teaching: Changing Relations in a Changing Context. Studies in Higher Education, 24, 293-301.

Brew, A. (2003). Teaching and research: new relationships and their implications for inquiry-based teaching and learning in higher education. Higher Education Research \& Development, 22, 3-18.

Brew, A. (2006). Research and teaching: beyond the divide. Hampshire: Palgrave Macmillan.

Commission of the European Communities (2002). Developing foresight for the development of higher education/research relations in the perspective of the European research area (ERA) (Brussels, European Commission, Directorate General for Research). 
521 Confederation of British Industry (2012). Learning to grow. What employers need from education and skills. Education and skills survey. CBI/Pearson, London.

Cuthbert, R. (2009). Can academic practice make perfect? Educational Developments SEDA, 10, 1-5. ISSN 1469-3267.

Decker, H. \& Wolff, S.W. (2016). Re-inventing Research-Based Teaching and Learning. Paper prepared for presentation at the meeting of the European Forum for Enhanced Collaboration in Teaching of the European University Association: 2016 December 5: Brussels. Centre for Education and Learning.

Dexter, B., \& Seden, R. (2012). "It's really making a difference": How small-scale research projects can enhance teaching and learning. Innovations in Education and Teaching International, 49, 83-93.

Eden, S. (2014). Out of the comfort zone: enhancing work-based learning about employability through student reflection on work placements. Journal of Geography in Higher Education, 38, 266276.

Felton, P. (2011). Monet moments and the necessity of productive disruption. Teaching and Learning in Higher Education. Winter 2011. Available at:

https://repository.brynmawr.edu/cgi/viewcontent.cgi?article=1005\&context=tlthe

Fuller, I. C., Mellor, A., \& Entwistle, J. A. (2014). Combining research-based student fieldwork with staff research to reinforce teaching and learning. Journal of Geography in Higher Education, 38, 383400 .

Fung, D. (2017). A Connected Curriculum for Higher Education. Education. UCL Press, London. https://doi.org/10.14324/111.9781911576358 
Geschwind, L. \& Broström, A. (2015). Managing the teaching-research nexus: ideals and practice in research-oriented universities. Higher Education Research and Development, 34, 60-73.

Griffiths, R. (2004). Knowledge production and the research-teaching nexus: the case of the built environment disciplines. Studies in Higher Education, 29, 709-726.

Haigh, M., Cotton, D. \& Hall, T. (2016). Pedagogic Research in Geography Higher Education. Routledge, UK.

Harris, T. \& Tweed, F. (2010). A research-led, inquiry-based learning experiment: classic landforms of deglaciation, Glen Etive, Scottish Highlands. Journal of Geography in Higher Education, 34, 511-528.

Hattie, J. \& Marsh, H.W. (1996). The relationship between research and teaching: A meta-analysis. Review of Educational Research, 66, 507-542.

Healey, M. (2005). Linking Research and Teaching to Benefit Student Learning. Journal of Geography in Higher Education, 29, 183-201.

Healey, M. \& Jenkins, A. (2009). Developing undergraduate research and inquiry. The Higher Education Academy, York, UK.

Healey, M., Blumhof, J. \& Thomas, N. (2003). The Research-Teaching Nexus in Geography. Earth and Environmental Sciences (GEES), Planet, Special Edition 5, 5-13.

Healey, M., Jordan, F., Pell, B., \& Short, C. (2010). The research-teaching nexus: a case study of students' awareness, experiences and perceptions of research. Innovations in Education and Teaching International, 47, 235-246. 
Healey, M., Flint, A. \& Harrington, K. (2014). Engagement through partnership: Students as partners in learning and teaching in higher education. York: HEA.

Hill, J., Blackler, V., Chellew, R., Ha, L. \& Lendrum, S. (2013). From researched to researcher: Student experiences of becoming co-producers and co-disseminators of knowledge. Planet, 27, 35-41.

Hill, J. \& Walkington, H. (2016) Developing graduate attributes through participation in undergraduate research conferences. Journal of Geography in Higher Education, 40, 232-237.

Hill, J., Thomas, G., Diaz, A. \& Simm, D. (2016). Borderland spaces for learning partnership: opportunities, benefits and challenges. Journal of Geography in Higher Education, 40, 375-393.

Hill, J., Walkington, H. and Kneale, P. (2018) Borderland spaces: Moving towards self-authorship. In: Bilham, T., Hamshire, C., Hartog, M. and Doolan, M., eds. (2018) Reframing Space for Learning: Empowering Excellence and Innovation in University Teaching and Learning. First. London: UCL/loE Press, pp. 1-15. ISBN 9781782772460

Hodge, D.C., Baxter Magolda, M.B. and Haynes, C.A. (2009). Engaged Learning: Enabling SelfAuthorship and Effective Practice. Liberal Education 95 Available at: https://www.aacu.org/publications-research/periodicals/engaged-learning-enabling-selfauthorship-and-effective-practice

Jenkins, A. (2000). The relationship between teaching and research: where does geography stand and deliver? Journal of Geography in Higher Education, 24, 325-351.

Jenkins, A. (2002). Developing the Research/Teaching Nexus: Suggestions for Course Teams. Teaching News, February, 3-5.

Jenkins, A. (2004). A guide to the research evidence on teaching-research relations. Heslington, 
606

607

608

609

610

611

612

613

614

615

616

617

618

619

620

UK: The Higher Education Academy, UK.

Jenkins, A., \& Healey, M. (2005.) Institutional strategies to link teaching and research. The Higher Education Academy, UK.

Jenkins, A., Breen, R. Lindsay, R. \& Brew, A. (2003). Re-shaping Higher Education: Linking Teaching and Research. London: Routledge/SEDA.

Johansson, C. \& Felton, P. (2014) Transforming Students: Fulfilling the Promise of Higher Education. John Hopkins Press, Baltimore MD.

Kinchin, I. M., \& Hay, D. B. (2007). The myth of the research-led teacher. Teachers and Learning:

Theory and Practice, 13, 43-61.

Le Heron; R; Baker, R \& McEwen, L. (2006). Co-learning: Re-linking Research and Teaching in Geography. Journal of Geography in Higher Education, 30, 77-87.

Lindsay, R., Breen, R. \& Jenkins, A. (2002). Academic research and teaching quality: the views of undergraduate and postgraduate students. Studies in Higher Education, 27, 309-327.

Marsh, H.W. \& Hattie, J. (2002). The Relation Between Research Productivity and Teaching Effectiveness. The Journal of Higher Education, 73, 603-641.

Mason, G., Williams, G \& Cranmer, S. (2009). Employability skills initiatives in higher education: what effects do they have on graduate labour market outcomes? Education Economics 1, 1-30.

McLean, M. \& Barker, H. (2004). Students making progress and the 'research-teaching nexus' debate. Teaching in Higher Education, 9, 407-419. 
Mitchell, R. L. (2006). Emanation and generation. About Campus, 11, 29-30.

Moore, N., Fournier, E.J., Hardwick, S.W., Healey, M., Maclachlan, J. \& Seemann, J. (2011). Mapping the Journey Toward Self-Authorship in Geography. Journal of Geography in Higher Education, 35, 351-364.

Moore-Cherry, N., Healey, R., Nicholson, D.T. \& Andrews, W. (2016). Inclusive partnership: enhancing student engagement in geography. Journal of Geography in Higher Education, 40, 84-103.

Morrar, R., Arman, H. \& Mousa, S. (2017). The Fourth Industrial Revolution (Industry 4.0): A Social Innovation Perspective. Technology Education and Management Review, 7 (11), 12-20.

Neary, M., Saunders, G. Hagyard, A. \& Derricott, D. (2014). Student as producer: research-engaged teaching, an institutional strategy. The Higher Education Academy, York, UK 52pp. Available online at: https://www.heacademy.ac.uk/knowledge-hub/student-producer-research-engaged-teachingand-learning-institutional-strategy

Palfreyman, D. \& Tapper, T. (2009). Structuring mass higher education: the role of elite institutions. New York: Routledge.

Pegg, A. Waldock, J., Hendy-Isaac, S. \& Lawton, R. (2012). Pedagogy for employability. York, UK: Higher Education Academy.

Robertson, J. (2007). Beyond the 'research/teaching nexus': Exploring the complexity of academic experience. Studies in Higher Education, 32, 541-556.

Schapper, J. \& Mayson, S.E. (2010). Research-led teaching: moving from a fractured engagement to a marriage of convenience. Higher Education Research \& Development, 29, 641-651. 
664 Simons, M. \& Elen, J. (2007). The research-teaching nexus' and 'education through research': an

665 exploration of ambivalences. Studies in Higher Education, 32, 617-631.

666

667 Speake, J. (2015). Navigating our way through the research-teaching nexus. Journal of Geography in 668 Higher Education, 39, 131-142.

669

670 Tight, M. (2016) Examining the research/teaching nexus. European Journal of Higher Education, 6:4, $671 \quad 293-311$.

672

673 Tweed, F. \& Boast, R. (2011). Reviewing the 'Research Placement' as a means of enhancing student

674 learning and expanding research capacity. Journal of Geography in Higher Education, 35, 599-615.

675

676 Walkington, H. (2015). Students as researchers: Supporting undergraduate research in the disciplines

677 in higher education. The Higher Education Academy, York, UK.

678

679 Walkington, H., Griffin, A. L., Keys-Mathews, L., Metoyer, S. K., Miller, W. E., Baker, R., \& France, D. 680 (2011). Embedding research-based learning early in the undergraduate geography curriculum. 681 Journal of Geography in Higher Education, 35, 315-330.

682

683 Zamorski, B. (2010). Research-led Teaching and Learning in Higher Education: A case. Teaching in 684 Higher Education, 7, 411-427.

685 


\begin{tabular}{|c|c|c|}
\hline Year & Project & $\begin{array}{c}\text { External } \\
\text { collaborator }\end{array}$ \\
\hline 2007-08 & Sustainable Communities I: Materials Development & \\
\hline 2007-08 & Doveridge Community Survey: Preservation and Sustainability & $\nabla$ \\
\hline 2008-09 & Sustainable Communities II: Data Management & \\
\hline 2008-09 & Developing Sustainable Building Materials: Clay-Plasterboard Blocks & $\square$ \\
\hline 2008-09 & Investigating Field Evidence of Scottish Highland Deglaciation & \\
\hline $2009-10$ & Developing a Fieldcourse Orientation Package: Virtual Catalunya I & \\
\hline 2009-10 & Ladyside Wood: Biostratigraphy and Sedimentology & \\
\hline $2009-10$ & Climate Change Adaptation I: Analysing Extreme Weather Events & $\square$ \\
\hline $2009-10$ & Faculty Green Group - Consultancy-Style Scoping Study & $\nabla$ \\
\hline $2009-10$ & Sustainable Communities III: 'Cycling Stoke' Project & $\square$ \\
\hline 2010-11 & Developing Sustainable Building Products: Unfired Brick Blocks & $\nabla$ \\
\hline $2010-11$ & Data Visualisations: Virtual Catalunya II & \\
\hline $2010-11$ & Climate Change Adaptation II: Developing Policy Instruments and Strategies & $\square$ \\
\hline $2010-11$ & Milldale Limestones: A Literature Review & \\
\hline 2011-12 & Faculty Audit of Environmental Indicators for the Green Group (2 GRAs) & \\
\hline 2011-12 & Environmental Issues in India: A Newspaper Audit & \\
\hline 2011-12 & Climate Change Adaptation III: Climate Change Risk Analysis & $\square$ \\
\hline $2012-13$ & I-Tree Assessment of Hanley Park: An Ecosystem Services Assessment & \\
\hline 2012-13 & Risk Governance in Iceland: A Literature Review & \\
\hline $2012-13$ & Water Saving Campaign: Behavioural Change Strategies & $\square$ \\
\hline $2012-13$ & The Hartshill Heritage Trail: Design, Testing and Production & $\square$ \\
\hline 2013-14 & Developing Hurricanes Resources for Schools & \\
\hline 2013-14 & Mobile Music and Urban Spaces: A Literature Review & \\
\hline 2013-14 & Landscape Quality Assessment of Fowlea Brook & $\square$ \\
\hline 2013-14 & Welcome Week Trail: Student Focus Groups and Trail Development & \\
\hline $2014-15$ & Developing Volcanic Hazards Materials for Schools & \\
\hline $2014-15$ & Peopling Big Data: Analysis of Data from Cycling Apps & \\
\hline 2014-15 & Sustainability West Midlands: Award Assessment and Management & $\nabla$ \\
\hline 2014-15 & Deprivation, Demographics and Community Activism & \\
\hline 2014-15 & Mapping the North-West Music Economy (2 GRAs) & \\
\hline $2015-16$ & Developing a Self-Guided Trail of the City of Stoke-on-Trent & \\
\hline 2015-16 & Visual Landscape Assessment in Iceland and Africa (2 GRAs) & \\
\hline $2015-16$ & Solar Power Feasibility Study & $\nabla$ \\
\hline $2015-16$ & Examining the Music Industry of North West England: Data Analysis & \\
\hline 2015-16 & Developing Earthquake Hazards Resources for Schools & \\
\hline 2017-18 & Evaluating Virtual Landscapes: A Survey of Gamers v Geographers & \\
\hline 2017-18 & Developing Mass Movement Hazards Resources for Schools & \\
\hline
\end{tabular}

Figure 1: Geography Research Assistantship Projects 
Figure 2: Vignettes of Geography Research Assistantship Projects

692

693

694

695

\section{Vignette 1}

\begin{tabular}{ll}
\hline Project & Mobile Music and Urban Spaces \\
\hline $\begin{array}{l}\text { Details of } \\
\text { activity }\end{array}$ & $\begin{array}{l}\text { The GRA worked with a member of staff to undertake preliminary research on } \\
\text { how new technologies of music listening are creating 'new geographies of } \\
\text { listening'. The work considered how listening to music 'on the move' (on } \\
\text { public transport, for example) shapes people's experiences of the spaces and } \\
\text { places that they inhabit, altering mood and helping to develop an emotional } \\
\text { attachment to place. }\end{array}$ \\
\hline Outcomes & $\begin{array}{l}\text { The work resulted in a co-authored research paper, published in the } \\
\text { International Journal of Urban and Regional Research }\end{array}$ \\
\hline Comments from & $\begin{array}{l}\text { "I have definitely acquired and strengthened already existing skills in } \\
\text { searching, analysing and linking academic materials, and then turning these } \\
\text { findings into a written piece. The collaboration in researching and writing } \\
\text { between myself and my research supervisor was also a new skill for me. I built } \\
\text { upon my time management skills and organisational skills also, due to the } \\
\text { independent nature of the assistantship. Working alongside a member of staff } \\
\text { on a piece of work boosted my confidence and gave me a sense of pride." }\end{array}$ \\
\hline $\begin{array}{l}\text { Comments from } \\
\text { staff }\end{array}$ & $\begin{array}{l}\text { “In the initial stages of the research assistantship, the student was tasked with } \\
\text { producing a detailed literature review. However, under their own initiative the } \\
\text { student went beyond this and began to critically evaluate the literature from a } \\
\text { conceptual standpoint. Project meetings therefore became much more than } \\
\text { the student 'presenting' a literature review, but rather in-depth conceptual } \\
\text { discussions. This enabled us to work together to identify a conceptual critique } \\
\text { of the literature that was subsequently published as a debates paper in a } \\
\text { leading journal." }\end{array}$ \\
\hline
\end{tabular}




\begin{tabular}{|c|c|}
\hline Project & Solar Power Feasibility Study \\
\hline $\begin{array}{l}\text { Details of } \\
\text { activity }\end{array}$ & $\begin{array}{l}\text { The GRA researched the feasibility of installing solar power at the UK } \\
\text { headquarters of an international chemicals business. They determined the cost } \\
\text { of such investment, potential savings on operation and payback on the } \\
\text { investment. They also examined the potential reduced carbon consumption of } \\
\text { the plant due to different solar power options. }\end{array}$ \\
\hline Outcomes & $\begin{array}{l}\text { The findings were written up as a report to the company and presented at the } \\
\text { firm's quarterly regional sales meeting. }\end{array}$ \\
\hline $\begin{array}{l}\text { Comments from } \\
\text { GRA }\end{array}$ & $\begin{array}{l}\text { "The ability to work unsupervised and then report back to my supervisor } \\
\text { enabled me to discover my own methods using remote sensing and site analysis } \\
\text { independently; this was challenging yet yielded useful results. I found the } \\
\text { experience to be highly rewarding and satisfying; where possible this module } \\
\text { template should be copied and applied especially where students have } \\
\text { demonstrated an ability to work well unsupervised. I enjoyed the independent } \\
\text { nature of the module, the freedom of deadlines and the interaction with non- } \\
\text { university organisations." }\end{array}$ \\
\hline $\begin{array}{l}\text { Comments from } \\
\text { staff }\end{array}$ & $\begin{array}{l}\text { "The project enabled the GRA to engage with real-world commercial decision } \\
\text { making for the energy budget of a UK subsidiary of an international speciality } \\
\text { chemical business. The energy analysis created by the GRA was welcomed by } \\
\text { the company at a critical stage of its financial planning. It also allowed the } \\
\text { GRA to gain workplace experience that could be useful in any further } \\
\text { employment in the sustainability or environmental fields. The project further } \\
\text { strengthened the University-Business link with the industry, which has led to } \\
\text { two students finding employment with the company in the past." }\end{array}$ \\
\hline $\begin{array}{l}\text { Comments from } \\
\text { external } \\
\text { collaborator }\end{array}$ & $\begin{array}{l}\text { "Excellent feasibility study on the use of renewable energy at our production } \\
\text { site. The study documentation showed evidence of an extensive on-site survey, } \\
\text { price comparison various types of renewable energy equipment and the } \\
\text { suitability of device installation. The presentation was clear and concise, with } \\
\text { a view to achieving } 100 \% \text { renewable electricity usage for our manufacturing } \\
\text { unit." }\end{array}$ \\
\hline
\end{tabular}




\section{Vignette 3}

\begin{tabular}{|c|c|}
\hline Project & Hartshill Heritage Trail \\
\hline $\begin{array}{l}\text { Details of } \\
\text { activity }\end{array}$ & $\begin{array}{l}\text { The GRA was responsible for researching the history of a local area of a North } \\
\text { Midlands city. Working with Committee members from the area's Residents' } \\
\text { Association, they identified buildings and other places of prominence for } \\
\text { inclusion in a heritage trail leaflet. The GRA also led on the design and } \\
\text { production of the trail text and graphics. }\end{array}$ \\
\hline Outcomes & $\begin{array}{l}\text { The chief project output was an illustrated trail leaflet, which has been well- } \\
\text { received. The GRA also led guided walks to mark the launch of the trail; these } \\
\text { were attended by the local MP, the Mayor and other civic dignitaries. }\end{array}$ \\
\hline $\begin{array}{l}\text { Comments from } \\
\text { GRA }\end{array}$ & $\begin{array}{l}\text { "I have a good work ethic, an interest in history and graphic design. I believe my } \\
\text { willingness to meet new people also helped with the success of this project, } \\
\text { because at times I needed to ask for residents' opinions, talk to a group of } 30 \\
\text { people on a walk, and to brief the residents' association committee members on } \\
\text { the progress of the project. Meeting with the Vice-Chancellor, a launch event } \\
\text { where around } 60 \text { people came for a guided walk, and the possibility for the trail } \\
\text { to be used as a welcome exercise for Geography students has shown that the } \\
\text { project has been recognised. Overall it has been a very useful experience in } \\
\text { terms of learning new skills and the project will definitely be going on my CV!" }\end{array}$ \\
\hline $\begin{array}{l}\text { Comments from } \\
\text { staff }\end{array}$ & $\begin{array}{l}\text { "This project was much more than finding out about the history of a local area. } \\
\text { It required the GRA to liaise with members of the local community to identify } \\
\text { locations of historic significance, design a route for the trail, and synthesise the } \\
\text { complex history of this area into a concise and coherent narrative that would be } \\
\text { accessible to the general public. Alongside this, the GRA honed their skills in } \\
\text { desk-top publishing as they were required to take the lead in the design and } \\
\text { production of the heritage trail leaflet, as well as gaining an insight into the } \\
\text { organisation and management of community events." }\end{array}$ \\
\hline $\begin{array}{l}\text { Comments from } \\
\text { external } \\
\text { collaborator }\end{array}$ & $\begin{array}{l}\text { "Working with a GRA from our local University enabled us to finally develop the } \\
\text { heritage trail which the Residents Association had been thinking about for } \\
\text { several years, but were unsure how to go about. We found the whole experience } \\
\text { immensely enjoyable and rewarding and were delighted with the final product } \\
\text { and the interest it generated within the local community. It also opened our } \\
\text { eyes to both the invaluable contribution that undergraduate students can make } \\
\text { to local communities, and that local communities can make to student learning" }\end{array}$ \\
\hline
\end{tabular}




\section{Vignette 4}

\begin{tabular}{|c|c|}
\hline Project & Sustainability West Midlands \\
\hline $\begin{array}{l}\text { Details of } \\
\text { activity }\end{array}$ & $\begin{array}{l}\text { The GRA worked with a not-for-profit company that acts as the sustainability } \\
\text { champion for the West Midlands, as designated by government. The GRA was } \\
\text { involved in updating a list of sustainability awards, removing any redundant } \\
\text { awards, conducting research to add more award schemes and selecting those } \\
\text { awards that they felt the company should be prioritising in future. }\end{array}$ \\
\hline Outcomes & $\begin{array}{l}\text { The findings were written up as a research report to the company and the GRA } \\
\text { also assisted with the company's Annual Conference. }\end{array}$ \\
\hline $\begin{array}{l}\text { Comments from } \\
\text { GRA }\end{array}$ & $\begin{array}{l}\text { "I found the module a welcome break from standard modules as it allowed me } \\
\text { to gain a better knowledge of a subject and gave me the opportunity to not only } \\
\text { meet people within a potential future employment area, but to also directly } \\
\text { relate the skills acquired elsewhere in my degree to a work place role. All the } \\
\text { research and report writing skills I have improved will aid me in further } \\
\text { education. My improved communication skills have enabled me to present } \\
\text { myself more confidently which should prove beneficial in any future career." }\end{array}$ \\
\hline $\begin{array}{l}\text { Comments from } \\
\text { staff }\end{array}$ & $\begin{array}{l}\text { "Involvement in this project enabled the GRA to employ and develop their } \\
\text { research skills and their subject knowledge in a relevant working environment, } \\
\text { which has clearly been of mutual benefit. The role was varied, as was the } \\
\text { nature of the contribution, with the GRA working to produce research of real } \\
\text { value and lasting benefit to the organisation." }\end{array}$ \\
\hline $\begin{array}{l}\text { Comments from } \\
\text { external } \\
\text { collaborator }\end{array}$ & $\begin{array}{l}\text { "A workplace-embedded GRA strikes the perfect balance between preparing an } \\
\text { undergraduate for the workplace and helping an employer to undertake research } \\
\text { tasks that would otherwise be difficult to complete. The GRA has enhanced the } \\
\text { reputation of the organisations I have worked for and been of consistent benefit } \\
\text { to them. The obvious benefit to the workplace is that of increased productivity } \\
\text { due to the support of GRAs; however, we have taken great pleasure in watching } \\
\text { the students enhance their talent and ability, but more critically their } \\
\text { confidence both in and out of the workplace. The positive impact of the GRA is } \\
\text { clearly demonstrated when you consider that a student who undertook the } \\
\text { module when I was in my previous role is now employed in that role herself. Her } \\
\text { research contribution during the GRA was cited as being a key reason for her } \\
\text { appointment, showing the importance of running this sort of initiative to open } \\
\text { up opportunities that can be increasingly difficult to find." }\end{array}$ \\
\hline
\end{tabular}




\section{Vignette 5}

\begin{tabular}{|c|c|}
\hline Project & Peopling Big Data - Cycling Apps \\
\hline $\begin{array}{l}\text { Details of } \\
\text { activity }\end{array}$ & $\begin{array}{l}\text { The GRA worked with a member of staff to undertake some preliminary research } \\
\text { into how cycling infrastructure reflected heat maps of cycling activity captured by } \\
\text { the activity tracking application Strava. The research involved identifying well- } \\
\text { used cycling routes in the city to investigate if the infrastructure was meeting the } \\
\text { needs of cyclists and whether the activity tracking data was a suitable tool for } \\
\text { informing active travel infrastructure decisions. }\end{array}$ \\
\hline Outcomes & $\begin{array}{l}\text { The work was presented to Stoke-on-Trent City Council and the Canals and Rivers } \\
\text { Trust informing officials of the issues of relying on Big Data for active travel } \\
\text { infrastructure decisions. The research was taken forward by the student forming } \\
\text { the basis for a PhD Studentship at Staffordshire University. }\end{array}$ \\
\hline $\begin{array}{l}\text { Comments from } \\
\text { GRA }\end{array}$ & $\begin{array}{l}\text { "I really enjoyed the module and was actually upset it had to end somewhere. I } \\
\text { would have liked to have carried on with it to see where even further research } \\
\text { would take the topic and even pursue it to its end. I enjoyed i) not being taught; } \\
\text { this was a self-motivating module where the work was largely done in discussions } \\
\text { or by research; ii) being able to conduct different types of research and further } \\
\text { the skills I have by using them in more ways and iii) the timescale - running over } \\
\text { the whole year I didn't feel rushed or pressured by the module. I improved my } \\
\text { research, report writing and presentation skills." }\end{array}$ \\
\hline $\begin{array}{l}\text { Comments from } \\
\text { staff }\end{array}$ & $\begin{array}{l}\text { "The GRA was tasked with identifying popular cycling routes in the city of Stoke- } \\
\text { on-Trent using the Strava Metro Heat Map as well as the Council's map of cycling } \\
\text { infrastructure. From this, they selected a sample of routes both on, and off-road, } \\
\text { to investigate. The student used a GoPro camera to captured segments of the } \\
\text { routes. The research highlighted that the perspective put forward by the Heat } \\
\text { Map and Council's infrastructure map differed substantially to the qualitative } \\
\text { experience of cycling the routes. Images and video were used to illustrate that } \\
\text { although routes were well-used, infrastructure was not functioning as it should. } \\
\text { Through the presentation the GRA learnt the value and impact of using various } \\
\text { visual methodologies - the Council were particularly interested in the findings } \\
\text { feeling that it gave them good insight into the issues facing cyclists in the city". }\end{array}$ \\
\hline
\end{tabular}




\section{Vignette 6}

\begin{tabular}{|c|c|}
\hline Project & Visual Landscape Assessment in Iceland and Africa \\
\hline $\begin{array}{l}\text { Details of } \\
\text { activity }\end{array}$ & $\begin{array}{l}\text { This work involved two GRAs working together with two staff. The GRAs conducted } \\
\text { analysis of data obtained from a pilot study of visual landscape quality assessment } \\
\text { in Iceland. Thereafter their roles became more distinct. One GRA produced a } \\
\text { review of the available literature concerning African landscape and the links to } \\
\text { anthropology and development. They also experimented with the development of } \\
\text { an African visual quality index. The other GRA produced a thorough review of the } \\
\text { available literature concerning landscape quality assessment in Iceland and adapted } \\
\text { - and voluntarily tested - a visual quality assessment method in Iceland in winter. }\end{array}$ \\
\hline Outcomes & $\begin{array}{l}\text { The GRAs prepared a report to go to participants of the Icelandic pilot study. } \\
\text { Elements of their collective research have informed a paper published in the } \\
\text { journal Land Use Policy. One of the GRAs is now working for the Field Studies } \\
\text { Council (FSC) and is part of ongoing related collaborative research between the FSC } \\
\text { and University staff on the visual quality assessment of landscapes. }\end{array}$ \\
\hline \multirow[t]{2}{*}{$\begin{array}{l}\text { Comments from } \\
\text { GRAs }\end{array}$} & $\begin{array}{l}\text { "I have developed the research and analytical skills associated with undertaking } \\
\text { research at a higher level. This module has been an incredible opportunity and one } \\
\text { of the highlights of my time at university. Not only have I got to work with two well } \\
\text { respected academics, I feel like I have made a genuine contribution to work they } \\
\text { are conducting. It was also quite a harsh introduction to academic writing, the back } \\
\text { and forth of papers as you think you've completed it, but more improvements are } \\
\text { suggested. This was challenging at first but reflecting on feedback to keep on track } \\
\text { and make the best possible final product became part of my learning routine." }\end{array}$ \\
\hline & $\begin{array}{l}\text { "My own written work has improved dramatically but also I have grown in } \\
\text { confidence in writing academic papers. Working as a team has enhanced my } \\
\text { teamwork and communication skills by being able to work with a group of people } \\
\text { and being willing to stick to deadlines. This has also had a roll-on-effect on my } \\
\text { organisation and time management skills. This module has been a fantastic } \\
\text { opportunity and I will definitely do it again if I had the opportunity, to be honest I } \\
\text { don't want it to finish and might continue some efforts in my own time." }\end{array}$ \\
\hline $\begin{array}{l}\text { Comments from } \\
\text { staff }\end{array}$ & $\begin{array}{l}\text { "The GRAs began this project as student researchers needing direction and ended it } \\
\text { as competent and confident stakeholders in this area of work. They developed a } \\
\text { clear sense of ownership and responsibility for many of the directions that the work } \\
\text { moved in, taking independent decisions as well as working with us as part of an } \\
\text { effective research team. Their groundwork was instrumental in enabling us to move } \\
\text { forward and related research is ongoing, with one of the GRAs continuing to } \\
\text { collaborate with us from their place of work." }\end{array}$ \\
\hline
\end{tabular}


Figure 3: A series of Geography Research Assistantships: connecting research and outreach in a colearning environment

\begin{tabular}{ll}
\hline Project & Developing hazards resources for use in schools \\
\hline Actors & $\begin{array}{l}\text { To-date, } 4 \text { GRAs over the last } 5 \text { years working with a University outreach coordinator, } \\
\text { an academic and a range of school teachers and pupils }\end{array}$ \\
\hline Rationale & $\begin{array}{l}\text { This ongoing project aims to help bridge the gap between 'A level' and } \\
\text { undergraduate student learning. So far, it has focused on natural hazards } \\
\text { (earthquakes, volcanic eruptions, hurricanes, landslides) and identifies aspects that } \\
\text { pupils find it difficult to grasp. It unites the domains of research and schools' } \\
\text { outreach and attracts GRAs who want to become schoolteachers. }\end{array}$ \\
\hline
\end{tabular}

$\begin{array}{ll}\text { Details of } & \text { GRAs usually begin by reviewing external examiners' reports to identify the issues } \\ \text { activity } & \text { that pupils struggle with. They have also reviewed different learning styles to create } \\ \text { a variety of resources to suit the needs of different learners. GRAs have typically } \\ \text { used a range of research methods to review the requirements of A-level students and } \\ \text { their teachers to produce appropriate resources which can be used both inside the } \\ \text { classroom or as learning and revision resources for students at home. }\end{array}$

Outcomes A range of resources have been produced that can be used to support the teaching of hazards in schools.

Comments from "It was hugely rewarding working as part of a team under direction and being able students to reinforce professional and study skills as part of independent research. I developed confidence in my aspirations to become a geography teacher. I really valued being more creative and using these skills to create resources which I can use in the future in my teaching career - not an opportunity I would have had otherwise."

(I "I enjoyed a different way of learning, the scope to do a variety of different things and the fact that this was not lecture-based. The experience gained during this module will be invaluable to my career."

2 "A brilliant opportunity, and a definite 'must take' module option. I enjoyed the nature of the module, that it was easier to fit around other modules and the range of skills gained."

2 "I gained confidence through presenting the findings and improved time management from the work diary which helps to keep you on track. It gives you the chance to develop and learn a range of new skills and also helps you to take control of your learning. I feel it has put me in great stead for both my academic and professional future."

Comments from education and outreach staff
(2) "It is a pleasure to see a student go beyond the call of duty and run with an idea utilising their creativity."

28 "She did a great job creating resources for use in school and could design a whole curriculum based on her understanding of the learning process!"

(2) "I was impressed with the development of resources, which rose to the challenge of simplifying material to be digested at different levels of learning."

(2) "The GRA really took ownership of the work, going out of their comfort zone to engage with challenging material on learning styles and hazard mechanisms." 
Figure 4: Student performance in assessment for the GRA module
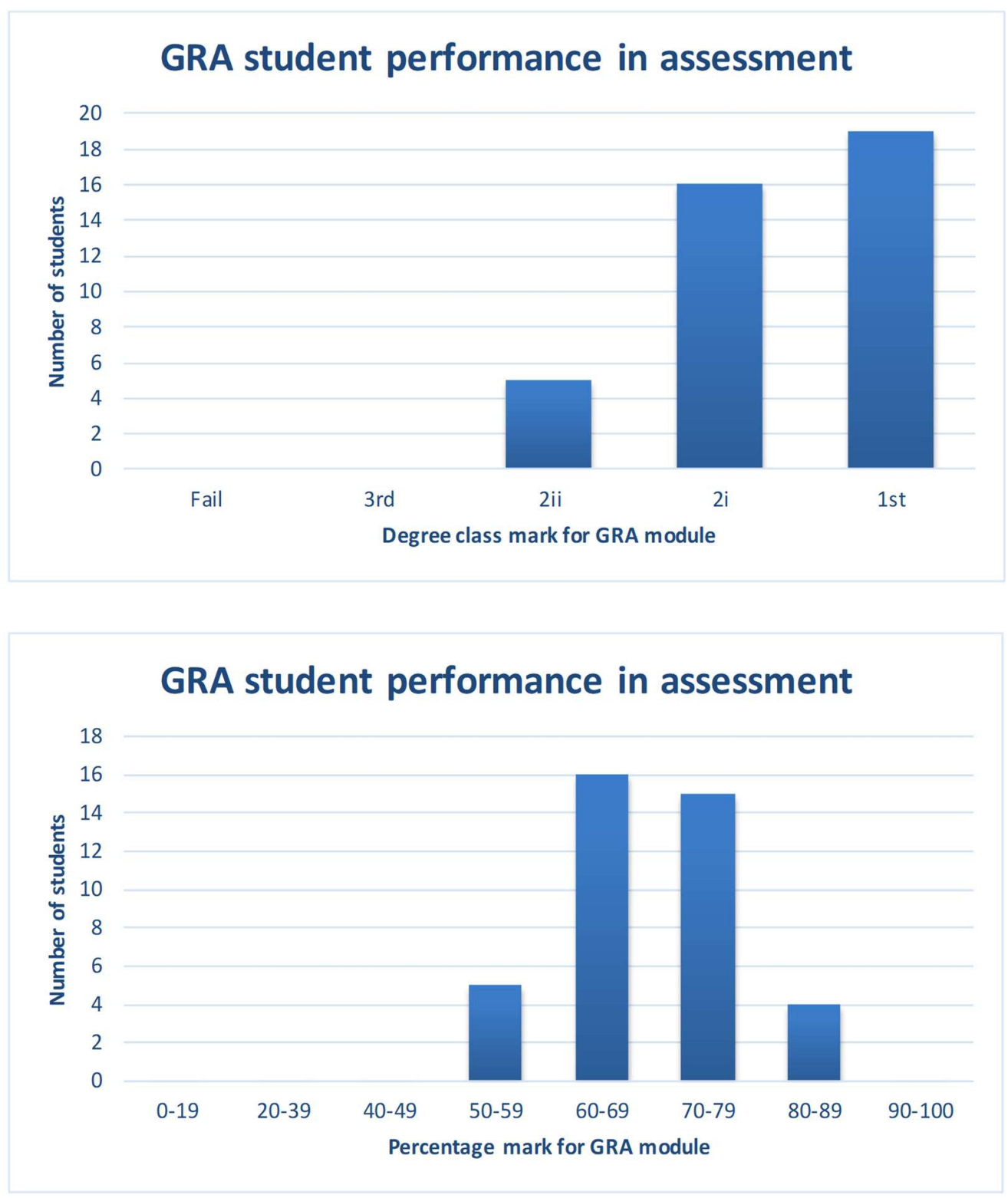
Figure 5: Summary of closed question responses to the Geography Research Assistantship student
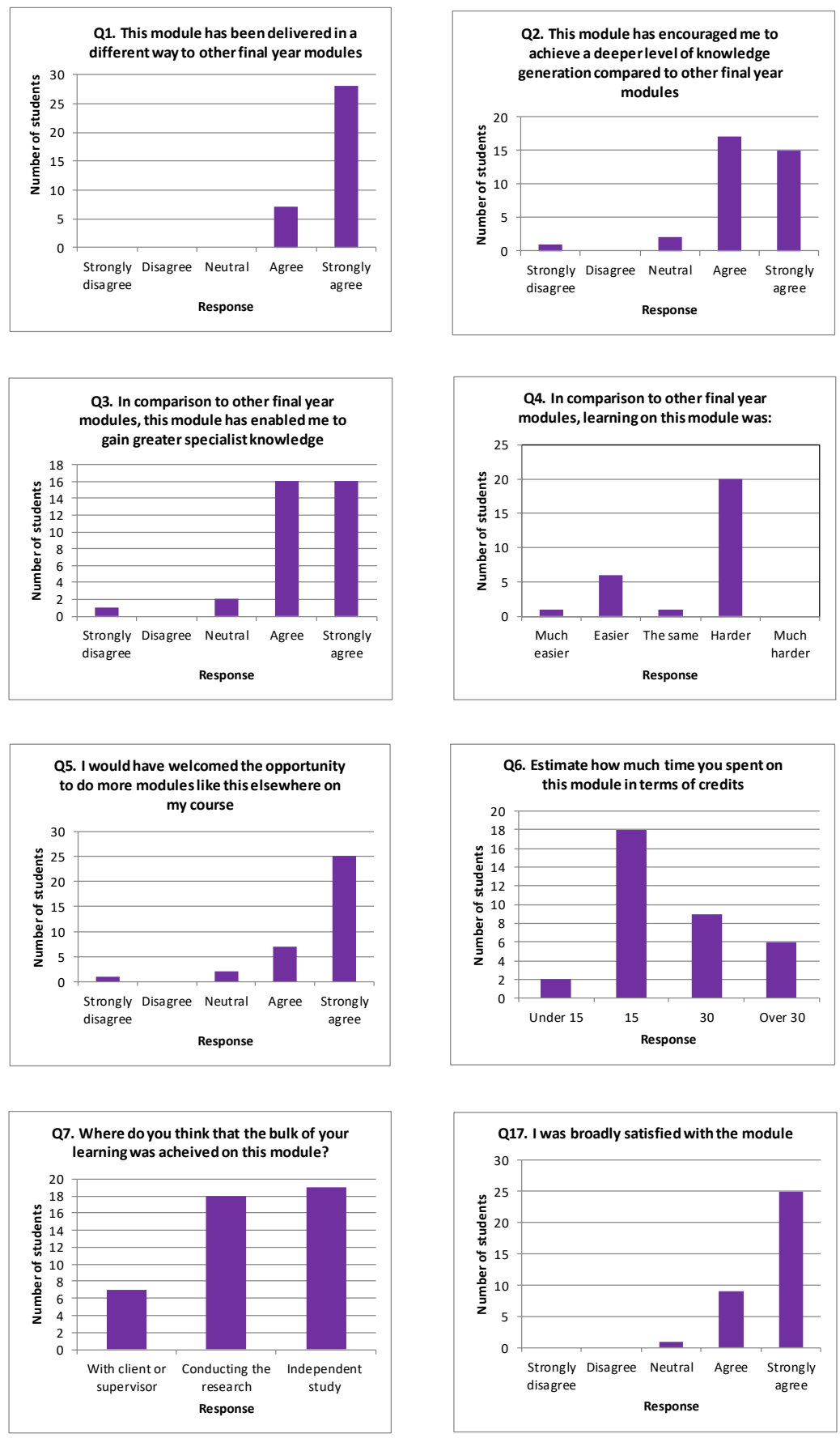
Figure 6: Skills and attributes identified by GRA students as part of the student feedback questionnaire

\section{Q8. Please describe the skills that you think you have acquired on this module}

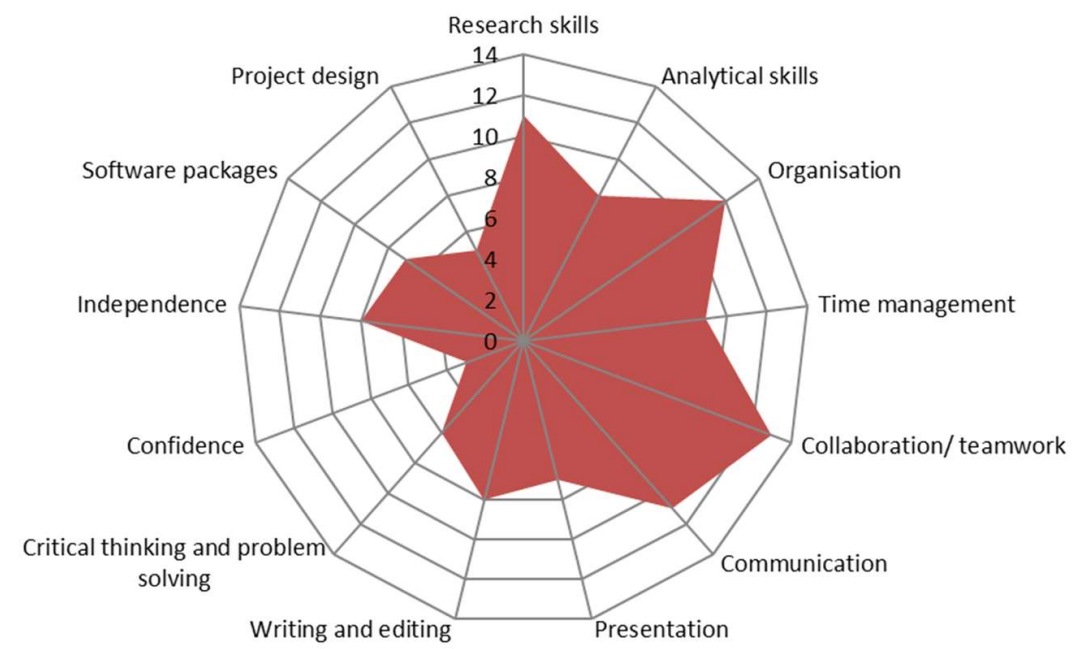

\section{Q14. What attributes and aptitudes do you think you need to have in} order to do this module?

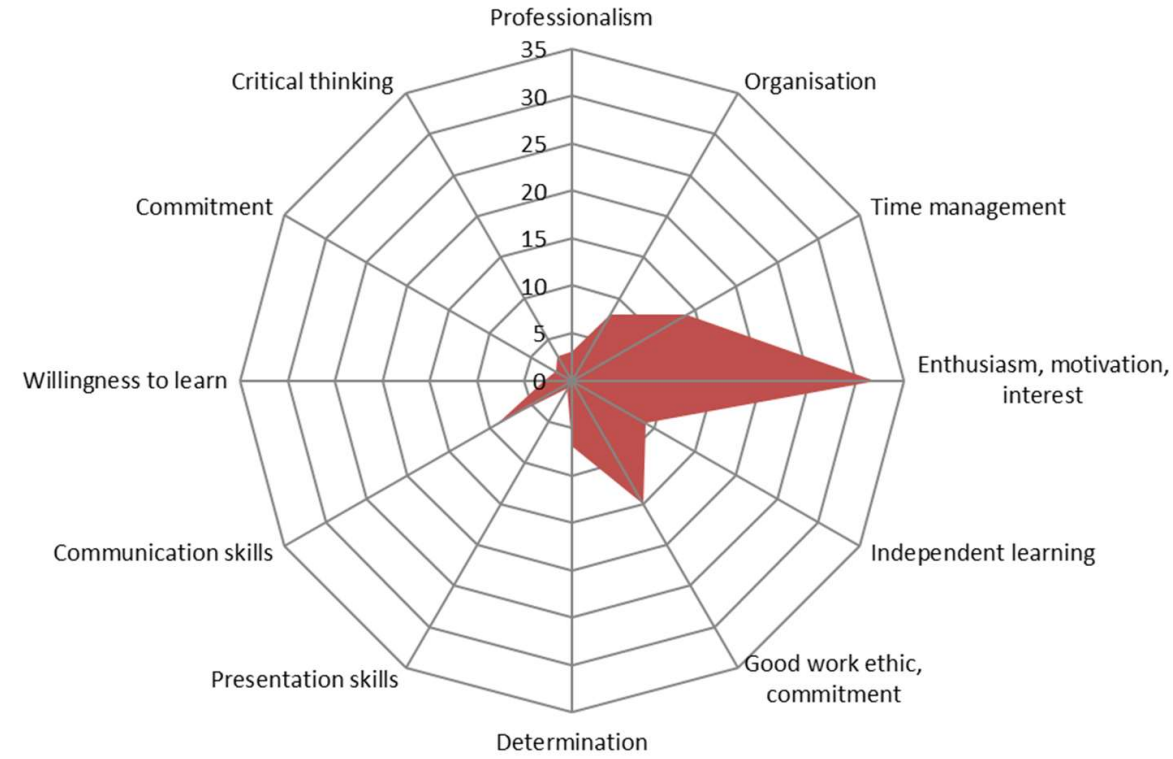

